\title{
Hospitalization as reliable indicator of second wave COVID-19 pandemic in eight European countries
}

\author{
Mattia Allieta, $\mathrm{PhD}^{1^{*}}$, Davide Rossi Sebastiano, MD, $\mathrm{PhD}^{2^{*}}$ \\ 1 - Ronin Institute Montclair, NJ 07043 USA \\ 2 - Neurophysiology Unit, IRCCS-Neurological Institute "Carlo Besta", via Celoria 11, 20133, Milan, Italy
}

\begin{abstract}
Time dependent reproduction number $\left(R_{\mathrm{t}}\right)$ is one of the most popular parameters to track the impact of COVID-19 pandemic. However, especially at the initial stages, $R_{t}$ can be highly underestimated because of remarkable differences between the actual number of infected people and the daily incidence of people who are tested positive. Here, we present the analysis of daily cumulative number of hospitalized (HP) and intensive care unit (ICU) patients both in space and in time in the early phases of second wave COVID-19 pandemic across eight different European countries, namely Austria, Belgium, Czech Republic, France, Italy, Portugal, Spain, and United Kingdom. We derive simple model equations to fit the time dependence of these two variables where exponential behavior is observed. Growth rate constants of HP and ICU are listed, providing country-specific parameters able to estimate the burden of SARS-COV-2 infection before extensive containment measures take place. Our quantitative parameters, fully related to hospitalizations, are disentangled from the capacity range of the screening campaign, for example the number of swabs, and they cannot be directly biased by the actual number of infected people. This approach can give an array of reliable indicators which can be used by governments and healthcare systems to monitor the dynamics of COVID-19 epidemic.
\end{abstract}

Keywords: COVID-19, SARS-CoV-2, Second Wave, Europe, ICU, hospitalization

\section{Corresponding authors:}

Mattia Allieta, PhD

Email: mattia.allieta@gmail.com

Davide Rossi Sebastiano, MD. PhD

Email: davide.rossi@istituto-besta.it

Funding: This research received no external funding

Conflicts of Interest: Authors declare no conflicts of interest

Patients Involvement: No patients were involved 
medRxiv preprint doi: https://doi.org/10.1101/2020.12.31.20249084; this version posted January 5, 2021. The copyright holder for this preprint (which was not certified by peer review) is the author/funder, who has granted medRxiv a license to display the preprint in perpetuity.

It is made available under a CC-BY-NC-ND 4.0 International license .

\section{Introduction}

Second wave COVID-19 pandemic constitutes an ongoing global threat and particularly in European Union (EU) which, according to World Health Organization (WHO), is again one of the epicenters of coronavirus epidemic (Han et al., 2020; Rypdal et al., 2020). From the first week of September, SARS-COV2 is rapidly spreading through almost all the EU countries and the cumulative incidence of official reported COVID-19 confirmed cases has reached more than 13 million on November $9^{\text {th }}$.

Usually, the time dependent reproduction number $R_{\mathrm{t}}$, (the average number of secondary cases generated by an infectious individual at time t) is considered one of the most important and informative parameters to track the epidemic trends (Riccardo et al., 2020; Rypdal et al., 2020). However, when it is huge the number of cases of a particular disease per unit of population (i.e. the morbility or morbidity rate, MB), as in COVID-19 pandemic, $R_{t}$ can be underestimated, simply because the diagnostic possibilities of a healthcare system are overwhelmed and the difference between actually infected people and infected people who are tested positive is very high. In this context, the calculation of $R_{t}$ is susceptible to mistakes which are very difficultly to be disentangled (Fan et al, 2020; Perico et al., 2020; Riccardo et al., 2020; Stefanelli et al., 2020; Whittaker et al., 2020).

On the other hand, mortality rates suffer from a time delay compared to the trend of the epidemic: the mean delay of 15 days between the death and the infection of COVID-19 makes this parameter virtually impractical for the decision-making, although it is one of the most reliable indicator of the pandemic by a theoretical point of view (Garcia-Basteiro et al., 2020).

Even more than the epidemic trends as itself, from the beginning of COVID-19 pandemic, two key variables represent, the major problems which the health care systems must face with: the number of hospitalized patients (HP) and the number of Intensity Care Units (ICU) patients. In each EU country, HP and ICU are affected by the limited available resources, a dramatic bottleneck with respect to the possibility of an adequate care of each patient affected by COVID-19. Hence, because of $R_{t}$ is an index strictly depending on the ratio between the number of swabs performed and $\mathrm{MB}$ and, at the same time, the mortality rate is a parameter temporally too far from the real situation to be used in the challenging epidemic context. HP and ICU are probably the only parameters representing a good compromise between reliability and solidity besides being remarkably useful in the decision making related to the COVID-19 pandemic. 
medRxiv preprint doi: https://doi.org/10.1101/2020.12.31.20249084; this version posted January 5, 2021. The copyright holder for this preprint (which was not certified by peer review) is the author/funder, who has granted medRxiv a license to display the preprint in perpetuity.

It is made available under a CC-BY-NC-ND 4.0 International license .

Mathematical modeling of spreading of respiratory infectious diseases is a well-established field in epidemiology (Wallinga and Teunis, 2004) and, recently, many works have been devoted to model SARS-COV2 spreading and the virus transmission dynamics (as example, for Italy, see Riccardo et al., 2020, Allieta et al., 2020). Moreover, these valuable theoretical efforts, statistical analysis obtained by parametrizing the ongoing epidemiological data could provide reliable starting experimental parameters to perform more accurate predictive calculations.

In this work, we focused on the relationship between the number of HP and ICU by deriving a simple model equation able to fit the observed time evolution of cumulative incidence for eight selected EU countries, namely Austria, Czech Republic, Italy, France, Belgium, Portugal, Spain, United Kingdom (UK), at the start of second wave COVID-19 pandemic, from August to November 2020. This allows us to obtain consistent parameters to strictly monitor the local dynamics of COVID-19 epidemic in all the country considered.

\section{Materials and Methods}

\subsection{Demographic and Epidemiological data}

The official demographic data of the resident population updated on January $1^{\text {st }}, 2020$ for each European Union country selected were taken from Eurostat. We collected data of COVID-19 epidemic for the eight European countries (i.e. Austria, Belgium, Czech Republic, France, Italy, Portugal, Spain and United Kingdom) from official websites where data are aggregated at national levels and published in form of dashboard, daily or periodical reported. All the data used in this work are accessible and have been publicly published (see also Table S1, supporting information, for all the details on demographic and epidemiological data sources). The data of COVID-19 pandemic were collected from August $1^{\text {st }}$ to October $31^{\text {st }}$ for all the country considered except Spain where data were available only from August $20^{\text {th }}$ to October $31^{\text {st }}$.

\subsection{Derivation of the time evolution equation of daily cumulative incidence of the number of hospitalized and intensive care unit patients related to COVID-19}

We assume that HP at time $t$ is N'HP and, over a short time interval of duration $\Delta t$ from $t$ to $(t+\Delta t)$, HP evolves to $k_{\mathrm{HP}} \Delta t \mathrm{~N}^{\prime}{ }_{\mathrm{HP}}$ for some constant $k_{\mathrm{HP}}$ defined as growth rate constant of 
HP. We can then approximate the change of population size $N_{H P}^{\prime}(t+\Delta)-N_{H P}^{\prime}(t)$ to $k_{H P} \Delta t N_{H P}^{\prime}(t)$ according to the following equality:

$N^{\prime}{ }_{H P}(t+\Delta)-N^{\prime}{ }_{H P}(t) \approx k_{H P} \Delta t N^{\prime}{ }_{H P}(t)$

Dividing both side by $\Delta$ t gives:

$\frac{N^{\prime}{ }_{H P}(t+\Delta)-N^{\prime}{ }_{H P}(t)}{\Delta t} \approx k_{H P} N_{H P}^{\prime}(t)$

The duration of $\Delta t$ must be short enough to ensure that the population size does not change too much and by considering the limit of $\Delta \rightarrow 0$ under the assumption of differentiable N'HP(t) function, it follows:

$\frac{d N^{\prime}{ }_{H P}(t)}{d t}=k_{H P} N_{H P}^{\prime}(t)$

We can solve equation (1.3) using separation of variables and by imposing that $N_{H P}^{\prime}(t)=$ $N_{H P}(t)-N_{H P, e}$ where $N_{H P}(t)$ is the ongoing cumulative HP at time $t$ and $N_{H P, e}$ is the cumulative HP of the "environment". More precisely, since the second wave develops from an equilibrium situation where $N_{H P}$ is not null, we assume for simplicity that the number of HP tends to an asymptotic "environmental" value exhibited before the $\mathrm{N}_{\mathrm{HP}}(t)$ started to grow exponentially.

$\int \frac{d\left(N_{H P}(t)-N_{H P, e}\right)}{N_{H P}(t)-N_{H P, e}}=k_{H P} d t$

Hence,

$\ln \left|N_{H P}(t)-N_{H P, e}\right|=k_{H P} t+C$

Solving for $N_{H P}(t)$ we get the following exponential growth equation:

$N_{H P}(t)=N_{H P, e}+C_{H P} e^{\mathrm{k}_{H P} t}$

We applied the same assumptions to derive the differential equation related to the time evolution of ICU which, by implementing the above conditions, reads as:

$N_{I C U}(t)=N_{I C U, e}+C_{I C U} e^{\mathrm{k}_{H P} t}$

Since it is reasonable to consider that $N_{\mathrm{ICU}}(\mathrm{t})$ can be strictly related to $N_{\mathrm{HP}}(\mathrm{t})$ such that a function like $N_{\mathrm{ICU}}=N_{\mathrm{ICU}}\left[N_{\mathrm{HP}}(\mathrm{t}), \mathrm{t}\right]$ is more appropriate to describe its evolution. However, 
our goal is to analyze $N_{\mathrm{ICU}}(\mathrm{t}), N_{\mathrm{HP}}(\mathrm{t})$ separately to define an empirical relationship between them. In this context, we used equations (1.5), (1.6) to fit the time evolution of $N_{\mathrm{ICU}}, N_{\mathrm{HP}}$ and to refine values of environmental hospitalized and ICU constants ( $\left.N_{\mathrm{HP}, \mathrm{e}}, N_{\mathrm{ICU}, \mathrm{e}}\right)$, empirical constants $\left(C_{\mathrm{HP}}, C_{\mathrm{ICU}}\right)$ and exponential growth rate parameters $\left(k_{\mathrm{HP}}, k_{\mathrm{ICU}}\right)$ directly against the observed data. Unit of measurement of $k_{\mathrm{HP}}, k_{\mathrm{ICU}}$ are in reciprocal day $\left(\mathrm{d}^{-1}\right)$ which allows to define generation time constants $G_{H P}=1 / k_{H P}, G_{I C U}=1 / k_{I C U}$ as the time in days (d) which elapsed between initial population and the population at $t$ of HP and ICU, respectively.

Furthermore, we defined a rate of conversion between $\mathrm{N}_{\mathrm{HP}}$ and $\mathrm{N}_{\mathrm{ICU}}$ patients as ICU rate of hospitalization patients $\left(R_{I C U}\right)$ and we made a connection between variables by adopting the simple equation:

$\widetilde{R_{I C U}}=\widetilde{N_{I C U}} / \widetilde{N_{H P}}$

where $\widetilde{N_{H P}}, \widetilde{N_{I C U}}$ are expressed as cumulative incidence per 100000 inhabitants.

\section{Results}

Results are summarized In figures S1-S4 (supporting information), where we reported the cumulative incidence as number of total HP and ICU patients for all the countries.

All the profiles were fitted by using equations (1.6), (1.7) and the results from non-linear squares regression are listed in Table S2. Models are in good agreement with both observed HP and ICU data sets as testified by high goodness of fit, i.e. coefficient of determination $\mathrm{R}^{2}$, ranging from 0.956 to 0.997 and from 0.962 and 0.996 for HP and ICU, respectively.

We noted that the lowest $\left(k_{H P}=0.056\right)$ and highest $\left(k_{H P}=0.115\right)$ values belong to neighboring Portugal and Spain, respectively, followed by France $\left(k_{H P}=0.082\right)$ and Belgium $\left(k_{H P}=0.084\right)$. We found that the $37.5 \%$ of investigated countries display a $k_{H P} \approx$ 0.06 with an average $k_{\mathrm{HP}}$ of $0.075 \pm 0.018$, according to values distribution (figure $1 \mathrm{a}$ ). When considering ICU parameters, we reported that lowest value is belong again to Portugal $\left(k_{\mathrm{ICU}}=0.049\right)$ while highest ones to Belgium $\left(k_{\mathrm{ICU}}=0.090\right)$ and Spain $\left(k_{\mathrm{ICU}}\right.$ $=0.086$ ). The values distribution is similar to HP (figure 1a) with the $37.5 \%$ of countries 
medRxiv preprint doi: https://doi.org/10.1101/2020.12.31.20249084; this version posted January 5, 2021. The copyright holder for this preprint (which was not certified by peer review) is the author/funder, who has granted medRxiv a license to display the preprint in perpetuity.

showing $k_{I C U} \approx 0.04$ and an average $k_{I C U}$ of $0.059 \pm 0.019$. G $G_{H P}$ varied from 9 to 18 days and $G_{I C U}$ from 11 to 26 days.

Surprisingly, we found that average $k_{H P}$ and $k_{I C U}$ are comparable and they can be related between each other as shown in Fig.1(b). A linear trend between the constants is then confirmed for all the countries, excluding France and Spain(figure 1b). This paves the way to delineate a more general correlation where for a given amount of HP a given amount of ICU can be then associated.

In figure 2a, we present the universal correlation between $\mathrm{N}_{\mathrm{HP}}$ and $\mathrm{N}_{\mathrm{ICU}}$ obtained by replotting all the observed data according to equation (1.8). $\mathrm{R}_{\mathrm{ICU}}$ obtained for all the countries together with $\mathrm{R}^{2}$ determination coefficient are listed in Table $\mathrm{S} 2$ and ranked in figure $2 b$.

For the most of the countries analyzed, $\mathrm{R}_{\mathrm{ICU}}$ followed the relation (1.8), excluding Czech Republic and France where higher $\mathrm{R}_{\mathrm{ICU}}$ is observed when the cumulative incidence HP is below 200000/100000 Inhabitants. We reported that 5 countries display an $\mathrm{R}_{\mathrm{ICU}}(\%)$ close to the mean value $14.6 \%(95 \% \mathrm{Cl}: 12.7 \%, 16.4 \%)$ while Italy and UK exhibit $\mathrm{R}_{\mathrm{ICU}} \approx 10 \%$. The highest $\mathrm{R}_{\mathrm{ICU}} \approx 18 \%$ is shown by France.

\section{Discussion}

In the year 2020, the COVID-19 pandemic determined the health and economic policy in all the EU countries. Based on the Chinese experience in the Hubei province and in the absence of effective treatments against the virus, to date, the most effective measures of public health to contain the pandemic have been non-pharmaceutical interventions such as quarantine, social distancing, and isolation of infected (Anderson et al., 2020). Although the restrictive measures taken by EU governments are necessary for the containment of the pandemic, they caused and they are still causing huge difficulties at individual, social and economic levels. Hence, given the impossibility of maintaining these restrictive measures for an unlimited period, all governments have worked to achieve a satisfactory balance based on reconciling economic and health needs. This can be done by restricting or by loosening the constraints imposed by the different epidemiological scenarios depending on the so called COVID-19 warning levels. In this context, it seems to be essential to have reliable and "manageable" indices to monitor the evolution of the epidemic trends. From a theoretical point of view, the actual reproduction number of infected people and the average reproduction number of secondary cases generated by 
medRxiv preprint doi: https://doi.org/10.1101/2020.12.31.20249084; this version posted January 5, 2021. The copyright holder for this preprint (which was not certified by peer review) is the author/funder, who has granted medRxiv a license to display the preprint in perpetuity. It is made available under a CC-BY-NC-ND 4.0 International license .

an infectious individual $\left(R_{t}\right)$ could be considered one of the most reliable and informative parameters to use. However, a huge difficulty is represented by the large number of infected people in an asymptomatic or mild condition (Oran and Topol, 2020). The lack of large-scale diagnostic tests (swabs) mainly due to economic and logistic reasons adopted by the different governmental authorities could cause a serious underestimation of the actual number of COVID-19 cases in the population (Perico et al., 2020; Riccardo et al., 2020; Whittaker et al., 2020), namely in case of high-incidence of the epidemic (Fan et al, 2020; Stefanelli et al., 2020). The problem of under-reporting the total number of actual infected patients distorts the epidemic trends (Fernández-Fontelo et al., 2020), making government measures potentially ineffective or even out of time. On the other hand, mortality rates suffer from a time delay compared to the trend of the epidemic. The mean delay of 15-20 days between the contraction of COVID-19 infection and the death makes this parameter virtually impractical for decision-making (Garcia-Basteiro et al., 2020). Here, we considered $\mathrm{N}_{H P}$ and $\mathrm{N}_{\mathrm{ICU}}$ taken as a cumulative incidence in eight EU countries (Austria, Belgium, Czech Republic, France, Italy, Portugal, Spain and United Kingdom) in the period between August $1^{\text {st }}$ and October $31^{\text {st }}$ (for Spain between August, $20^{\text {th }}$ and October $\left.31^{\mathrm{st}}\right)$, evaluating their relationship by means of several indices to determine if some of them can be considered effective to monitor the pandemic trends. In particular, by considering August $1^{\text {st }}$ as a starting point, we believe that the exponential growth of cumulative incidence observed up to October $31^{\text {st }}$, could offer a wide time window to extract intrinsic characteristic parameters related to the SARS-COV2. Moreover, this can be done before the effects of more stringent containment measures start to deeply affect the time evolution of epidemic.

As preliminary considerations, first we want to point out that we did not consider the cumulative number of new COVID-19 tested positive cases $\left(\mathrm{N}_{\mathrm{t}}\right)$, for the reasons described previously, i.e. $\mathrm{N}_{\mathrm{t}}$ is strictly dependent on the number of swabs performed and it can be biased by several factors like underreporting, delays in recording as well as errors in classification of cases. Then, we only focused on the data of the second wave of COVID19 epidemic because the beginning of the pandemic was quite different across the countries considered and the analysis techniques to monitor the spreading of the epidemic (mainly molecular swabs) were developed during the pandemic peak. Moreover, the last part of the summer period (August) can be considered as a sort of steady-state of the epidemic characterized by consistent epidemiological data which are useful to analyze the subsequent variations in the daily incidence of hospitalizations from COVID-19. Indeed, it 
medRxiv preprint doi: https://doi.org/10.1101/2020.12.31.20249084; this version posted January 5, 2021. The copyright holder for this preprint (which was not certified by peer review) is the author/funder, who has granted medRxiv a license to display the preprint in perpetuity. It is made available under a CC-BY-NC-ND 4.0 International license .

should be noted that similar approaches were impossible to follow during the first wave where the "submerged" infections were too much to allow an accurate estimation of the actual numbers (Apolone et al., 2020).

Even if the magnitude of the cumulative incidence of HP and ICU is quite different from one country to another, we found that the fitted growth rate constants are similar between each other, confirming that HP and ICU are strictly related in linear time-independent relationship obviously until effective containment measures were taken. Interestingly, UE countries apparently unrelated shared the same evolution of the pandemic trends: after about forty days from August $1^{\text {st }}$, in which the epidemic had a low and / or linear growth rate, the growth rate constants related to HP and ICU for all the studied UE countries started to have an exponential regime as marked by vertical dashed lines in Fig.S1-S4). We observed Austria which started to show exponential behavior of $N_{\text {HP }}$ after September $8^{\text {th }}$ followed by Portugal and Belgium on September $12^{\text {th }}$ and $13^{\text {th }}$, respectively. Czech Republic, France and United Kingdom shared the same onset on September $14^{\text {th }}$ while Italy featured late onset on October $7^{\text {th }}$. Again, Spain displayed a one-of-a-kind time dependence showing exponential growth chart only after October $13^{\text {th }}$. The origin of this relationship is not completely explainable for the huge socio-demographic, environmental/climatic factors, even if three main causes could have strongly favored the second wave at the beginning of autumn season: the reopening of schools (Larosa et al., 2020), the lowering of the temperatures (Guasp et al., 2020; Rovetta and Castaldo, 2020) and of the solar irradiance (Guasp et al., 2020). The analysis of such correlations is beyond the scope of this paper and it will be the subject of our future investigations, although it is possible to hypothesize that the southern countries (Italy and Spain) had fewer infections than northern ones due to the hot summer of 2020 . Beyond the "absolute" numbers related to HP and ICU, an "intrinsic" COVID-19-related epidemic trends seemed to emerge, again until effective containment measures were taken.

On the other hand, other parameters seem to be specific to each individual country, mainly $\mathrm{K}_{\mathrm{HP}}$ and $\mathrm{K}_{\mathrm{ICU}}$. Since $\mathrm{K}_{\mathrm{HP}}$ and $\mathrm{K}_{\mathrm{ICU}}$ are related to the generation time (generation time = $1 / K)$, these two indices can be profitably used to predict when hospital systems and / or intensive care units may become saturated. This could be important to promptly implement effective containment measures, as the resources available for each country are not infinite. It should be noted that the only limitation in the use of the parameters related to the hospitalization of COVID-19 patients is the delay of these indices with respect to the actual situation (Garcia-Basteiro et al., 2020). However, 
medRxiv preprint doi: https://doi.org/10.1101/2020.12.31.20249084; this version posted January 5, 2021. The copyright holder for this preprint (which was not certified by peer review) is the author/funder, who has granted medRxiv a license to display the preprint in perpetuity.

It is made available under a CC-BY-NC-ND 4.0 International license .

it has been reported that this delay is less pronounced than those relating to deaths caused by the virus (Garcia-Basteiro et al., 2020).

Finally, $\mathrm{R}_{\text {icu }}$ represents the "conversion rate" between HP and ICU (i.e., hospitalized patients who subsequently need to be transferred to intensive care units) and, together with $\mathrm{N}_{\text {icu }}$ could be used to (roughly) evaluate the efficiency of the first-level health care (home therapy and prompt hospitalization), albeit indirectly. $\mathrm{N}_{\text {icu }}$ depends more on the intrinsic dynamics of the COVID-19 epidemic (albeit conditioned by government measures and socio-demographic and environmental characteristics) than effectiveness of the health system. When both $\mathrm{N}_{\text {icu }}$ and $\mathrm{R}_{\text {icu }}$ are high, the ICU (the number of patients in intensive care units) depends on the large number of hospitalized patients according to the above linear relationship between HP and ICU assuming an adequate first-level health care. Vice versa, when $\mathrm{N}_{\text {icu }}$ is high and $\mathrm{R}_{\text {icu }}$ is low, the health system is probably inadequate and the high ICU can depend on the high number of patients admitted directly to intensive care, due to insufficient home therapy and / or delayed hospitalization.

\section{Conclusion}

Epidemiologically, the second wave COVID-19 pandemic is an intricate phenomenon, where some intrinsic characteristics of the transmission dynamics of the SARS-COV 2 are strictly entangled with socio-demographic and environmental variables which are not easy to interpret However, we showed that observed parameters like the number of hospitalization and ICU can be used as reliable indicators to map the ongoing epidemic evolution. This can provide a tool to plan adequately containment measures which can be taken in the light of forecasts adapted to the real situation.

\section{Acknowledgements}

It is impossible to name all the people who helped us in this difficult period, but we must thank the informal group "Legere", made up of doctors and researchers from Bergamo, Brussels, Frankfurt am Main and Genoa, for their continuous support. 
medRxiv preprint doi: https://doi.org/10.1101/2020.12.31.20249084; this version posted January 5, 2021. The copyright holder for this preprint (which was not certified by peer review) is the author/funder, who has granted medRxiv a license to display the preprint in perpetuity.

It is made available under a CC-BY-NC-ND 4.0 International license .

\section{Bibliography}

Allieta, M.; Allieta, A.; Sebastiano, D.R. COVID-19 outbreak in Italy: Estimation of reproduction numbers over two months toward the Phase 2. medRxiv 2020.,

doi: https://doi.org/10.1101/2020.05.12.20076794

Anderson RM, Heesterbeek $\mathrm{H}$, Klinkenberg D, Hollingsworth TD. How will country-based mitigation measures influence the course of the COVID-19 epidemic? Lancet. 2020 Mar 21;395(10228):931934. doi: 10.1016/S0140-6736(20)30567-5.

Apolone G, Montomoli E, Manenti A, Boeri M, Sabia F, Hyseni I, Mazzini L, Martinuzzi D, Cantone L, Milanese G, Sestini S, Suatoni P, Marchianò A, Bollati V, Sozzi G, Pastorino U. Unexpected detection of SARS-CoV-2 antibodies in the prepandemic period in Italy. Tumori. 2020 Nov 11:300891620974755. doi: 10.1177/0300891620974755.

Fan C, Liu L, Guo W, Yang A, Ye C, Jilili M, Ren M, Xu P, Long H, Wang Y. Prediction of Epidemic Spread of the 2019 Novel Coronavirus Driven by Spring Festival Transportation in China: A Population-Based Study. Int J Environ Res Public Health. 2020 Mar 4;17(5):1679. doi: 10.3390/ijerph17051679.

Fernández-Fontelo A, Moriña D, Cabaña A, Arratia A, Puig P. Estimating the real burden of disease under a pandemic situation: The SARS-CoV2 case. PLoS One. 2020 Dec 3;15(12):e0242956. doi: 10.1371/journal.pone.0242956.

García-Basteiro AL, Chaccour C, Guinovart C, Llupià A, Brew J, Trilla A, Plasencia A. Monitoring the COVID-19 epidemic in the context of widespread local transmission. Lancet Respir Med. 2020 May;8(5):440-442. doi: 10.1016/S2213-2600(20)30162-4.

Guasp M, Laredo C, Urra X. Higher Solar Irradiance Is Associated With a Lower Incidence of Coronavirus Disease 2019. Clin Infect Dis. 2020 Nov 19;71(16):2269-2271. doi:

$10.1093 /$ cid/ciaa575.

Han E, Tan MMJ, Turk E, Sridhar D, Leung GM, Shibuya K, Asgari N, Oh J, García-Basteiro AL, Hanefeld J, Cook AR, Hsu LY, Teo YY, Heymann D, Clark H, McKee M, Legido-Quigley H. Lessons learnt from easing COVID-19 restrictions: an analysis of countries and regions in Asia Pacific and Europe. Lancet. 2020 Nov 7;396(10261):1525-1534. doi: 10.1016/S01406736(20)32007-9.

Larosa E, Djuric O, Cassinadri M, Cilloni S, Bisaccia E, Vicentini M, Venturelli F, Giorgi Rossi P, Pezzotti P, Bedeschi E; Reggio Emilia Covid-19 Working Group. Secondary transmission of COVID-19 in preschool and school settings in northern Italy after their reopening in September 
medRxiv preprint doi: https://doi.org/10.1101/2020.12.31.20249084; this version posted January 5, 2021. The copyright holder for this preprint (which was not certified by peer review) is the author/funder, who has granted medRxiv a license to display the preprint in perpetuity.

It is made available under a CC-BY-NC-ND 4.0 International license .

2020: a population-based study. Euro Surveill. 2020 Dec;25(49):2001911. doi: 10.2807/15607917.ES.2020.25.49.2001911.

Oran DP, Topol EJ. Prevalence of Asymptomatic SARS-CoV-2 Infection : A Narrative Review. Ann Intern Med. 2020 Sep 1;173(5):362-367. doi: 10.7326/M20-3012

Perico L, Tomasoni S, Peracchi T, Perna A, Pezzotta A, Remuzzi G, Benigni A. COVID-19 and lombardy: TESTing the impact of the first wave of the pandemic. EBioMedicine. 2020 Nov;61:103069. doi: 10.1016/j.ebiom.2020.103069.

Riccardo F, Ajelli M, Andrianou XD, Bella A, Del Manso M, Fabiani M, Bellino S, Boros S, Urdiales AM, Marziano V, Rota MC, Filia A, D'Ancona F, Siddu A, Punzo O, Trentini F, Guzzetta G, Poletti P, Stefanelli P, Castrucci MR, Ciervo A, Di Benedetto C, Tallon M, Piccioli A, Brusaferro S, Rezza G, Merler S, Pezzotti P; COVID-19 working group. Epidemiological characteristics of COVID-19 cases and estimates of the reproductive numbers 1 month into the epidemic, Italy, 28 January to 31 March 2020. Euro Surveill. 2020 Dec;25(49):2000790. doi: 10.2807/1560-7917.

Rovetta A, Castaldo L. Relationships between Demographic, Geographic, and Environmental Statistics and the Spread of Novel Coronavirus Disease (COVID-19) in Italy. Cureus. 2020 Nov 9;12(11):e11397. doi: 10.7759/cureus.11397.

Rypdal K, Bianchi FM, Rypdal M. Intervention Fatigue is the Primary Cause of Strong Secondary Waves in the COVID-19 Pandemic. Int J Environ Res Public Health. 2020 Dec 21;17(24):E9592. doi: 10.3390/ijerph17249592.

Wallinga J, Teunis P. Different epidemic curves for severe acute respiratory syndrome reveal similar impacts of control measures. Am J Epidemiol. 2004 Sep 15;160(6):509-16. doi:

10.1093/aje/kwh255.

Whittaker R, Grøsland M, Buanes EA, Beitland S, Bryhn B, Helgeland J, Sjøflot OI, Berild JD, Seppälä E, Tønnessen R, Telle K. Hospitalisations for COVID-19 - a comparison of different data sources. Tidsskr Nor Laegeforen. 2020 Dec 14;140(18). English, Norwegian. doi:10.4045/tidsskr.20.0759. 


\section{FIGURE}

Figure 1 - Correlation between Cumulative Incidence HP and Cumulative incidence ICU
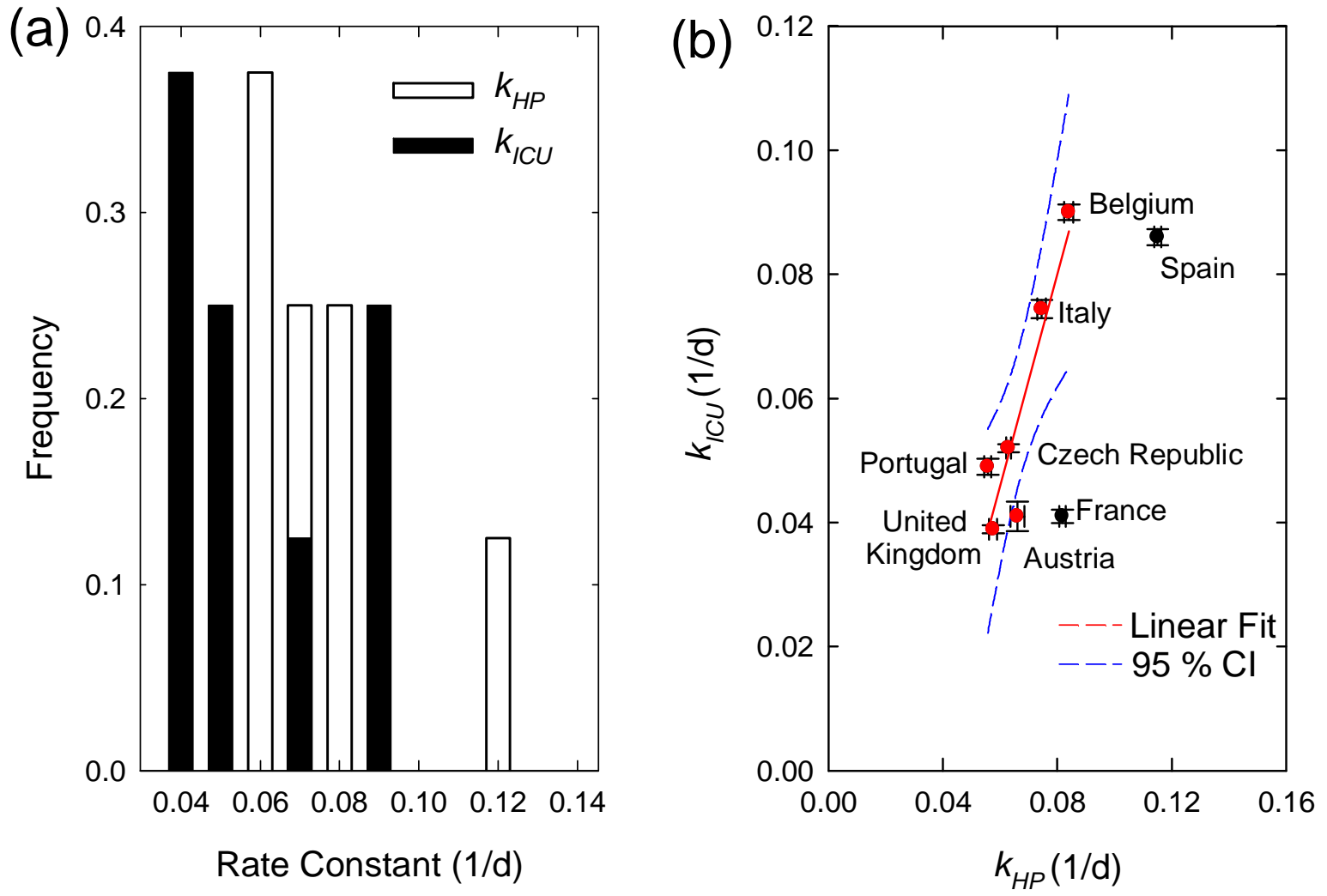

Legend: (a) Observed distribution of rate constants HP $\left(k_{\mathrm{HP}}\right)$ and ICU $\left(k_{\mathrm{ICU}}\right)$ determined in each region. (b) Correlation between $k_{\mathrm{HP}}, k_{\mathrm{ICU}}$; red and black dots represent countries in which $k_{\mathrm{ICU}} / k_{\mathrm{HP}}$ is included or not included in the $\mathrm{Cl}=95 \%$ of the linear fit model, respectively. 
medRxiv preprint doi: https://doi.org/10.1101/2020.12.31.20249084; this version posted January 5, 2021. The copyright holder for this preprint (which was not certified by peer review) is the author/funder, who has granted medRxiv a license to display the preprint in perpetuity.

It is made available under a CC-BY-NC-ND 4.0 International license .

Figure 2 - Correlation between Cumulative Incidence HP and Cumulative incidence ICU
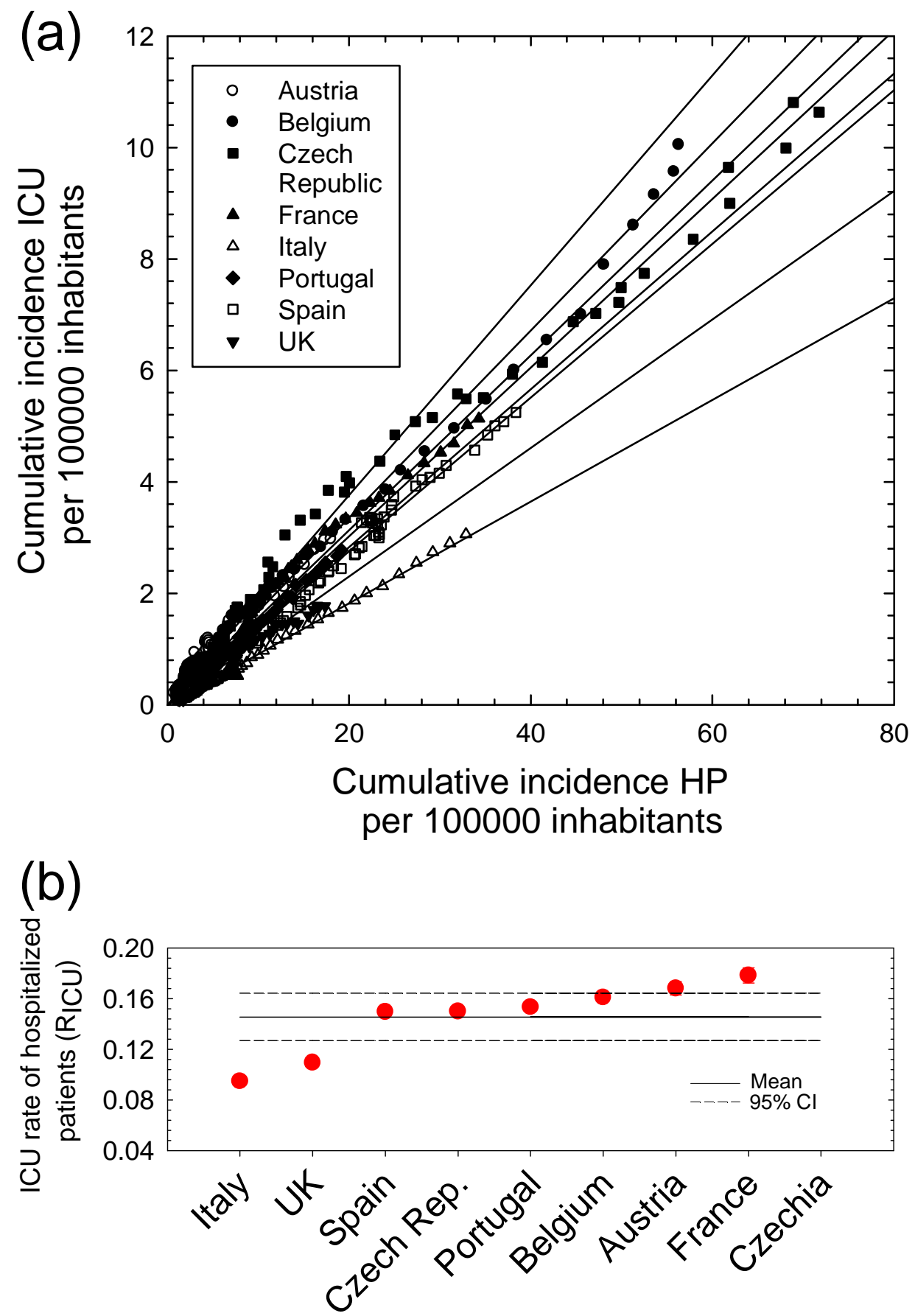

Legend: (a) Correlation between cumulative incidence HP and Cumulative incidence ICU for each country analyzed. Data are normalized over Country Population. Solid lines are linear fitting model. (b) ICU rate of hospitalized patients ( $\left.R_{I C U}\right)$ compared and ranked for all the selected countries; red and black dots represent countries in which $\mathrm{R}_{\mathrm{ICU}}$ is included or not included in the $\mathrm{Cl}=95 \%$ of the linear fit model, respectively. 


\section{SUPPORTING INFORMATION}

Figure S1 - Cumulative Incidence for hospitalized and ICU patients

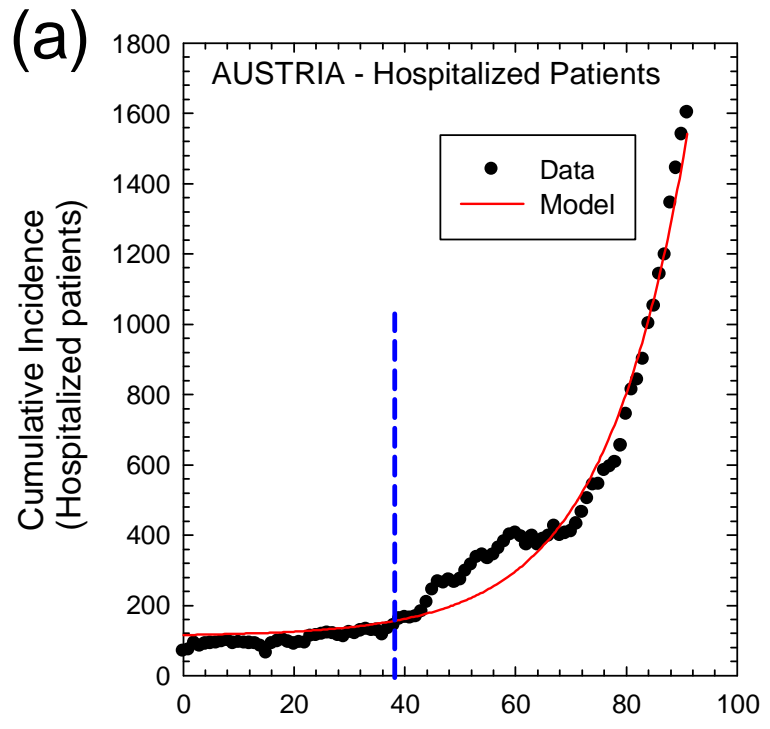

Day from August 1 st, 2020

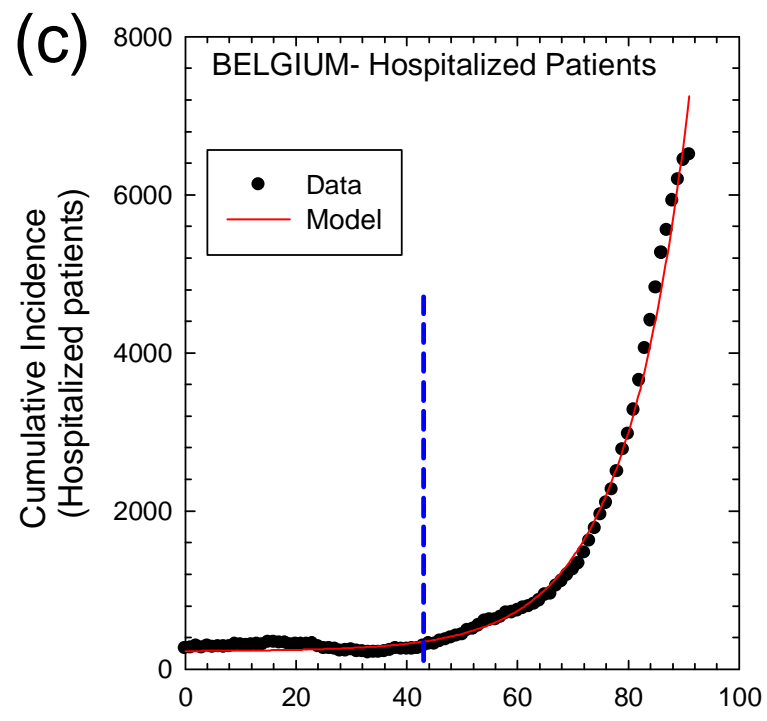

Day from August 1 1 st, 2020

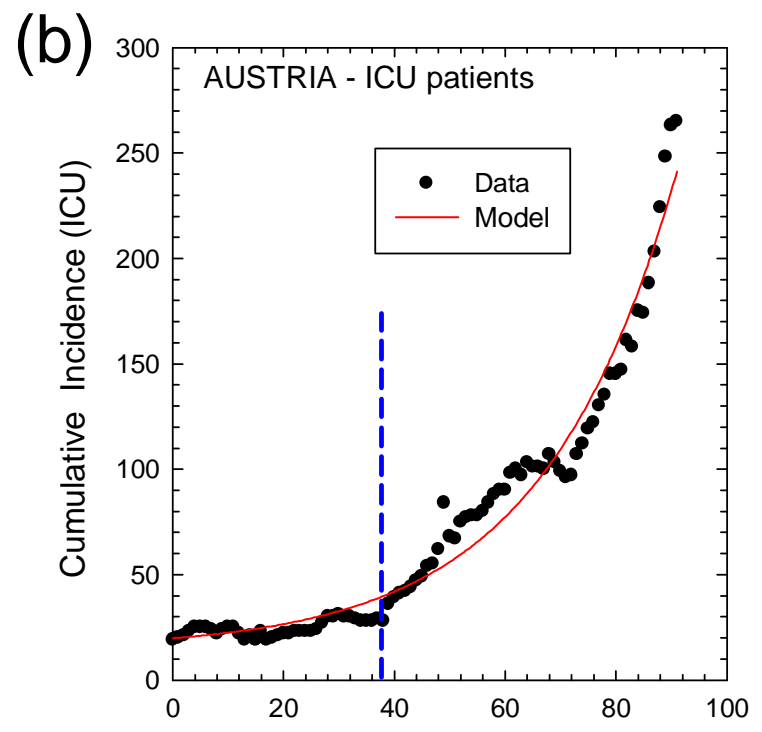

Day from August 1 st, 2020

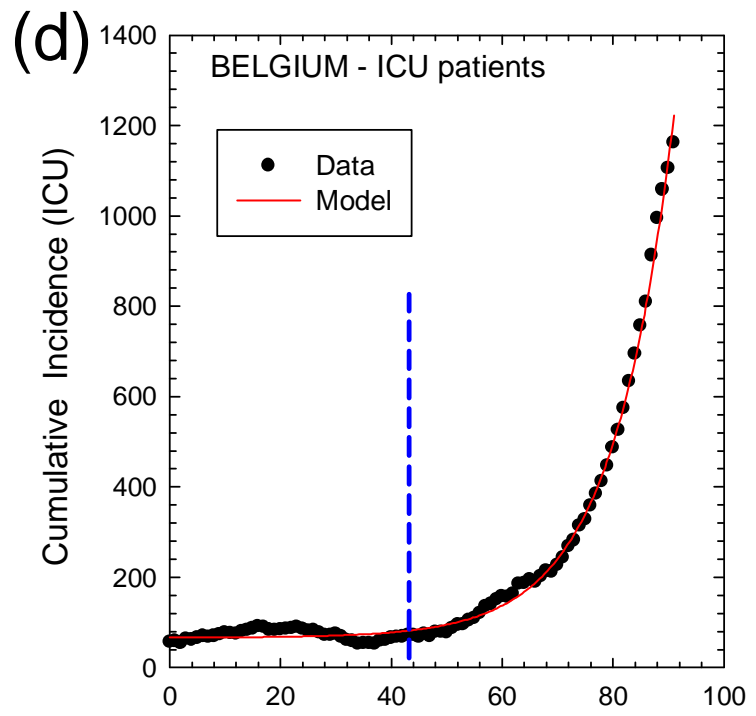

Day from August 1 st, 2020

Legend: Cumulative incidence as numbers of total hospitalized patients (left panel) and ICU patients (right panel) from August $1^{\text {st }}$ to October $31^{\text {st }}, 2020$ for COVID-19 in Austria (a), (b) and Belgium (c), (d), respectively. Dots represent observed data and solid lines the fitting curves, respectively. Vertical dashed lines mark the day after which exponential regime is observed. 
Figure S2 - Cumulative Incidence for hospitalized and ICU patients

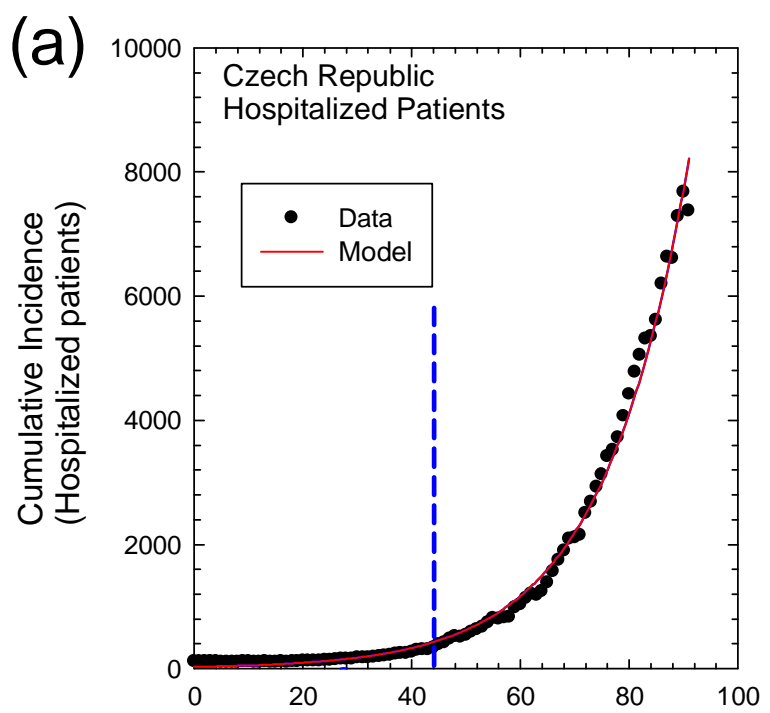

Day from August $1^{\text {st }}, 2020$

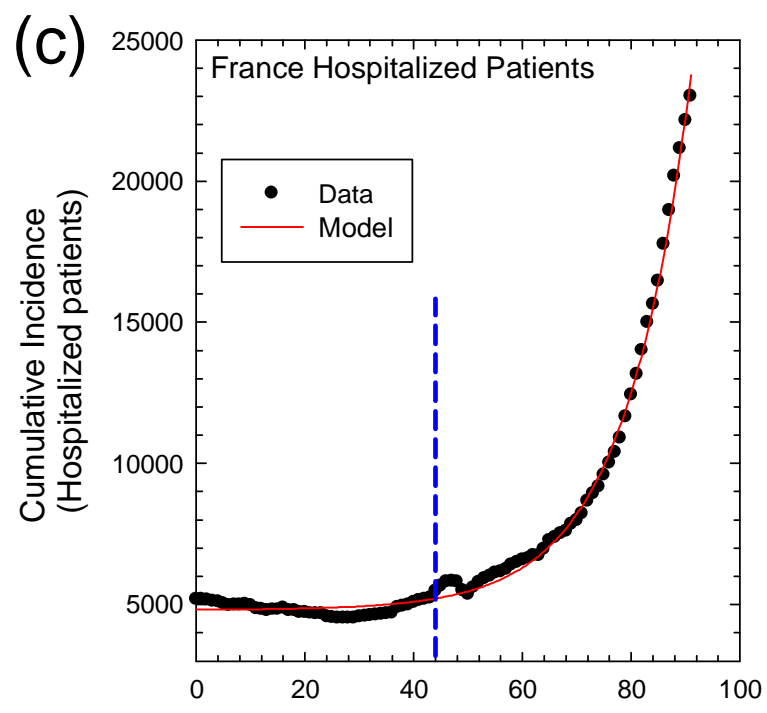

Day from August 1 st, 2020

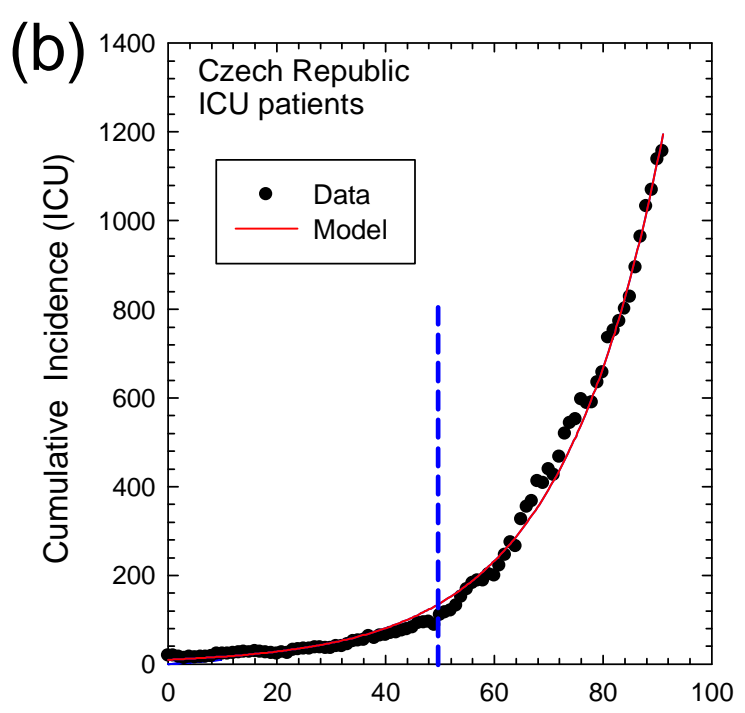

Day from August 1 st, 2020

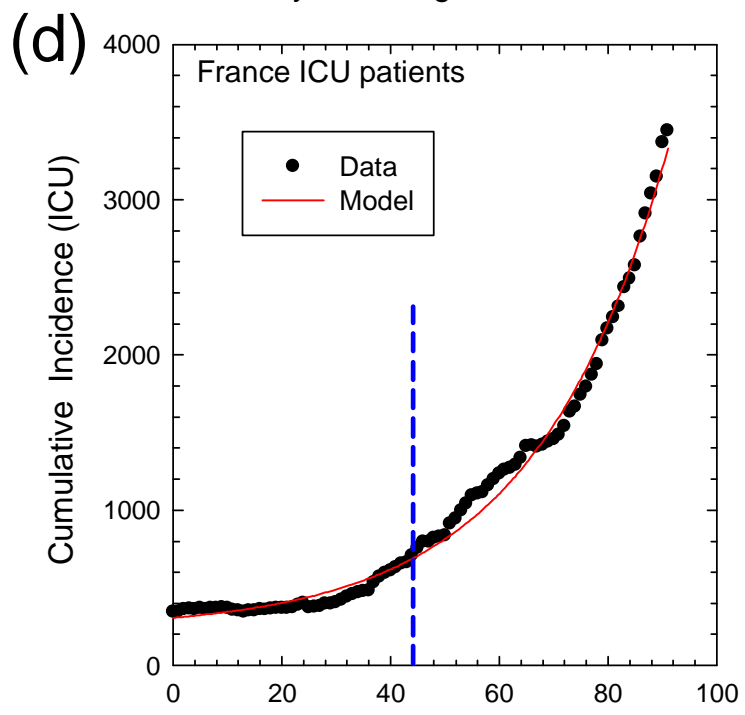

Day from August 1 st, 2020

Legend: Cumulative incidence as numbers of total hospitalized patients (left panel) and ICU patients (right panel) from August $1^{\text {st }}$ to October $31^{\text {st }}, 2020$ for COVID-19 in Czech Republic (a), (b) and France (c), (d). Dots represent observed data and solid lines the fitting curves, respectively. Vertical dashed lines mark the day after which exponential regime is observed. 
(a)

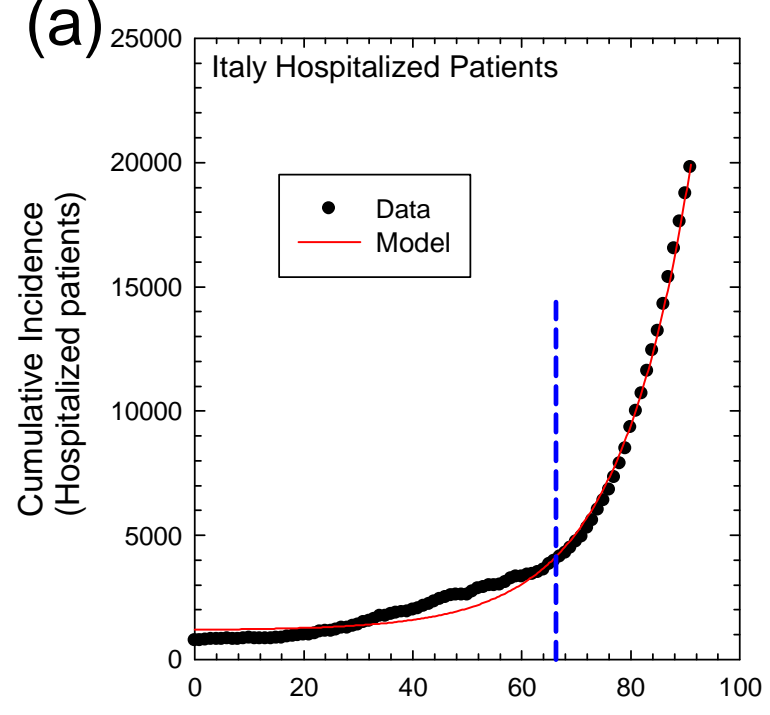

(c)

Day from August 1 ${ }^{\text {st }}, 2020$

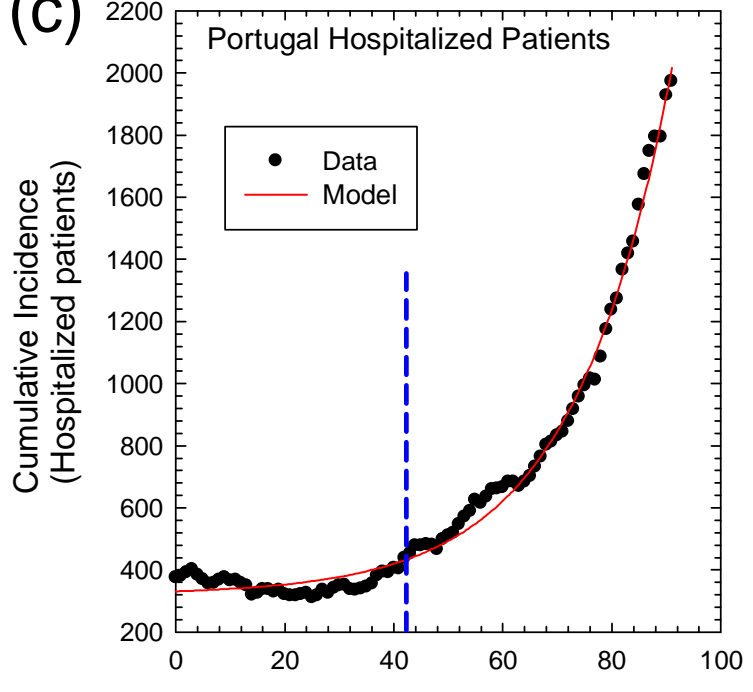

Day from August $1^{\text {st }}, 2020$

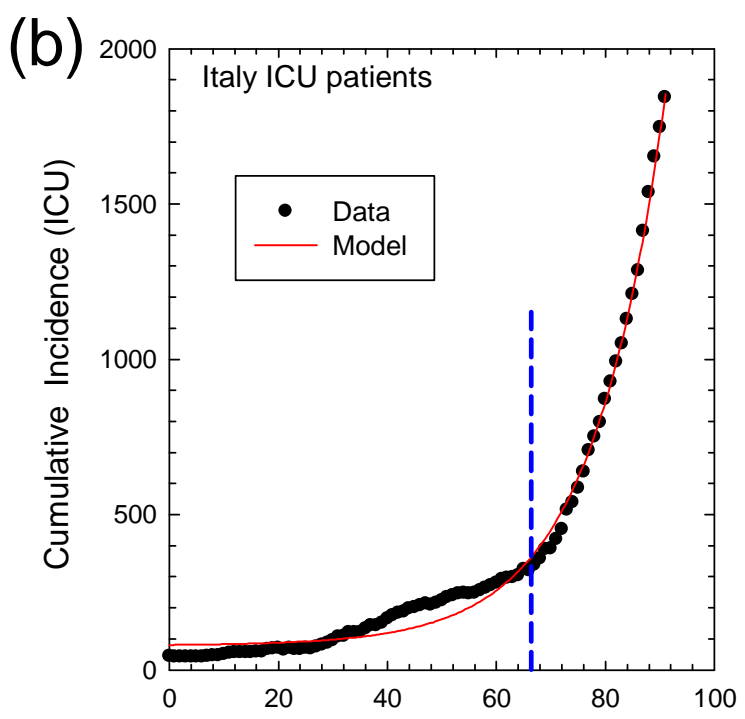

Day from August 1st, 2020

(d)

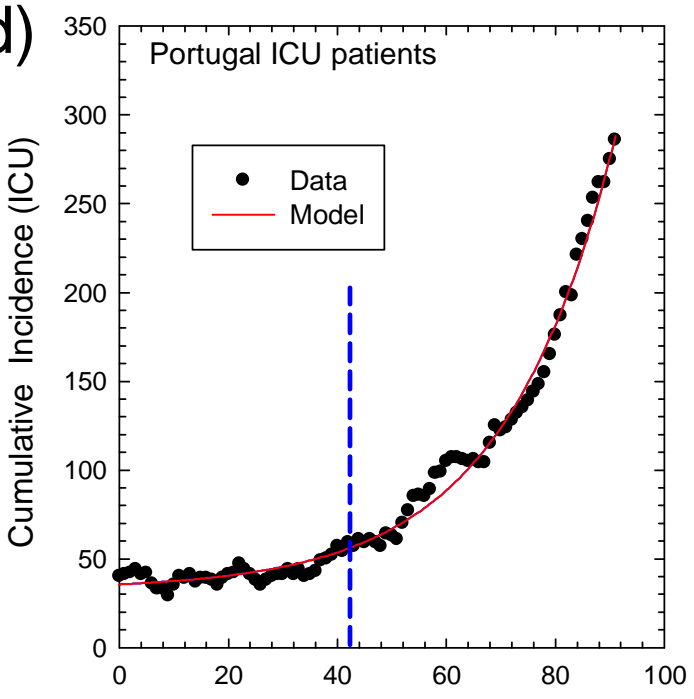

Day from August 1st, 2020

Legend: Cumulative incidence as numbers of total hospitalized patients (left panel) and ICU patients (right panel) from August $1^{\text {st }}$ to October $31^{\text {st }}, 2020$ for COVID-19 in Italy (a), (b) and Portugal (c), (d). Dots represent observed data and solid lines the fitting curves, respectively. Vertical dashed lines mark the day after which exponential regime is observed. 
Figure S4 - Cumulative Incidence for hospitalized and ICU patients

(a)

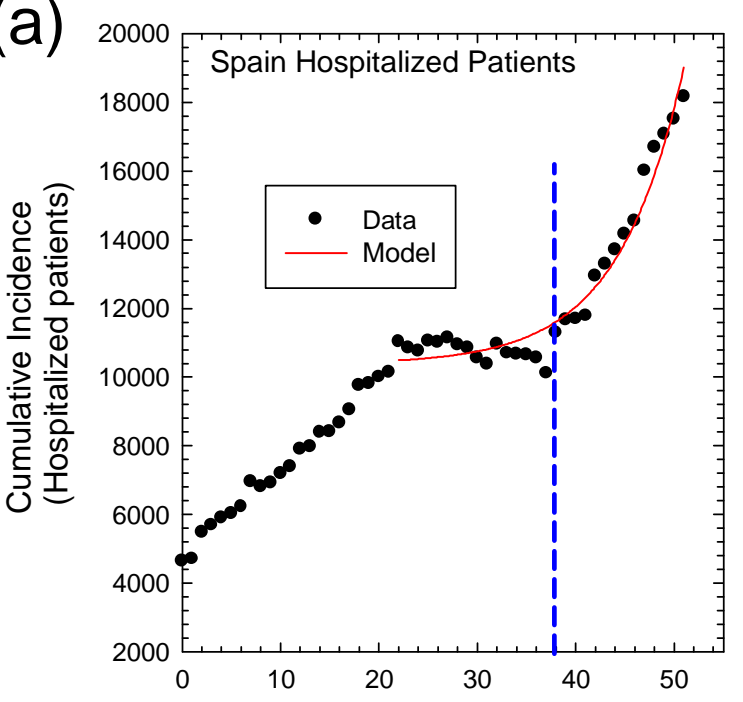

Day from August $20^{\text {th }}, 2020$

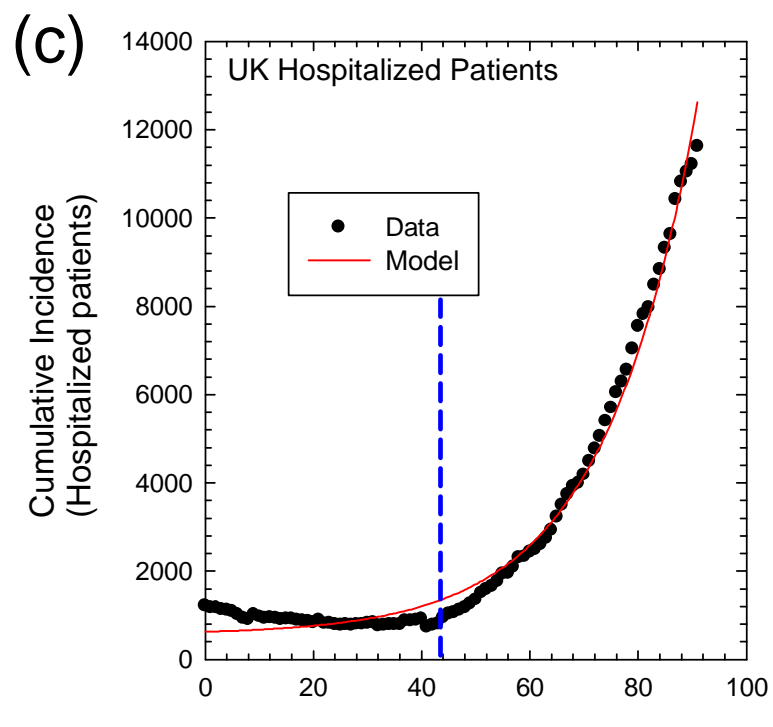

Day from August 1 1 st, 2020

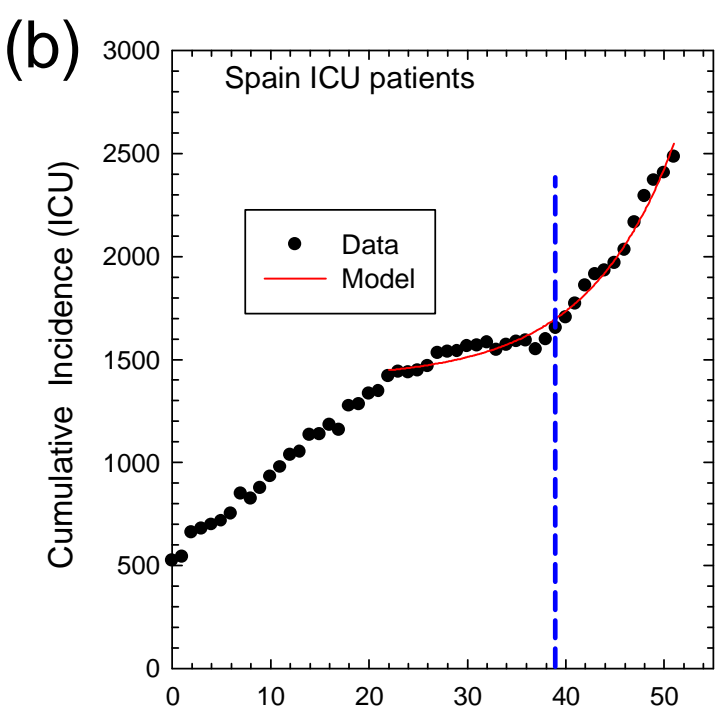

Day from August $20^{\text {th }}, 2020$

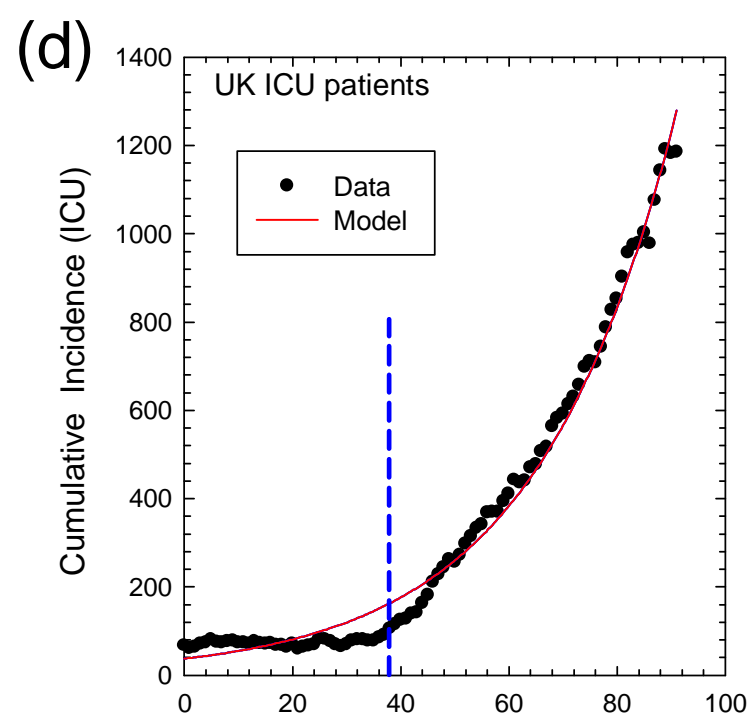

Day from August 1 st, 2020

Legend: Cumulative incidence as numbers of total hospitalized patients (left panel) and ICU patients (right panel) from August $20^{\text {st }}$ to October $31^{\text {st }}, 2020$ for COVID-19 in Spain (a), (b) and from August $1^{\text {st }}$ to October $31^{\text {st }}, 2020$ for COVID-19 in United Kingdom (c), (d). Dots represent observed data and solid lines the fitting curves, respectively. Vertical dashed lines mark the day after which exponential regime is observed. 
medRxiv preprint doi: https://doi.org/10.1101/2020.12.31.20249084; this version posted January 5, 2021. The copyright holder for this preprint (which was not certified by peer review) is the author/funder, who has granted medRxiv a license to display the preprint in perpetuity.

It is made available under a CC-BY-NC-ND 4.0 International license .

Table S1: Population and sources of data for countries considered

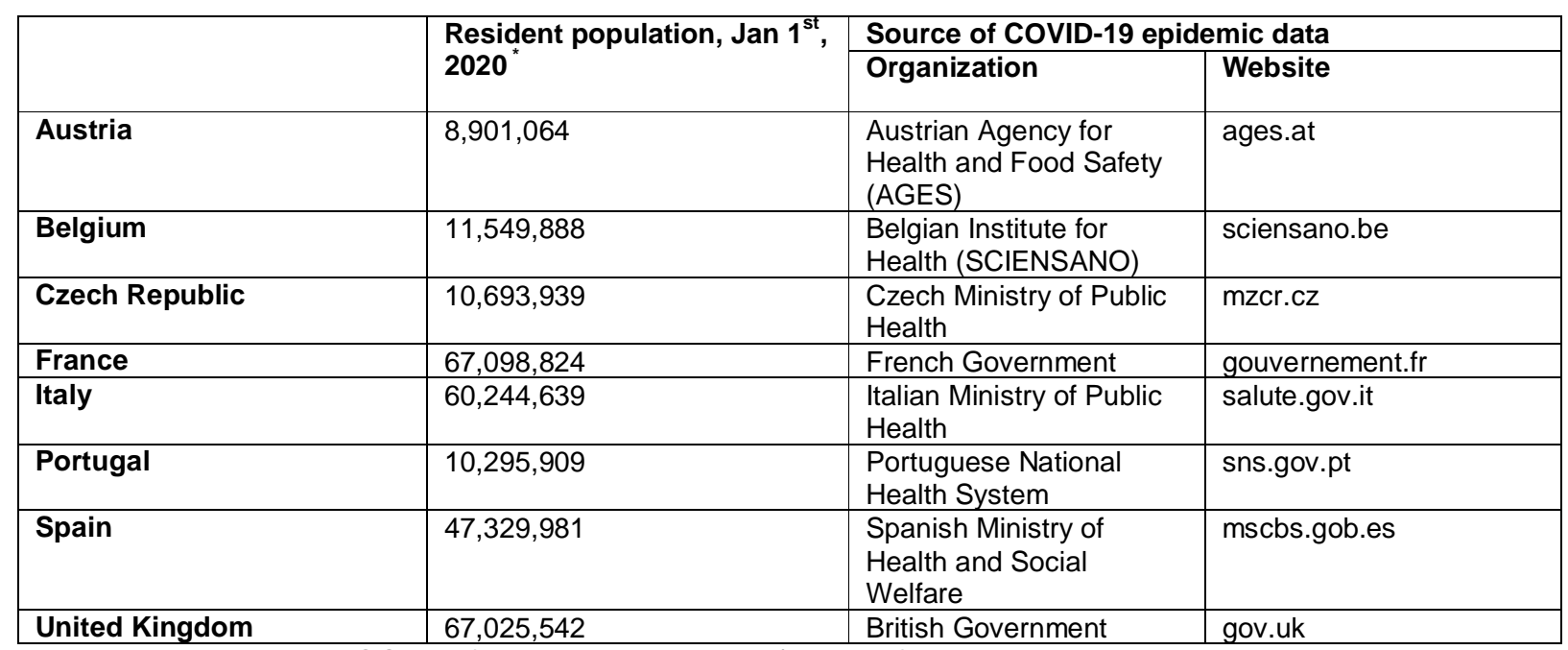

* Data taken from EUROSTAT (website ec.europa.eu/Eurostat)

Table S2. Results of epidemic parameters considered for each country

\begin{tabular}{|c|c|c|c|c|c|c|c|c|c|c|c|}
\hline & \multicolumn{4}{|c|}{ Hospitalization indices } & \multicolumn{4}{|c|}{ ICU indices } & \multicolumn{3}{|c|}{$\begin{array}{l}\mathbf{R}_{\mathbf{I C u}} \text { and related } \\
\text { indices }\end{array}$} \\
\hline & $\mathrm{N}_{\mathrm{HP}, \mathrm{e}}{ }^{*}$ & $\mathrm{C}_{\mathrm{HP}}$ & $\mathrm{k}_{\mathrm{HP}}$ & $\mathrm{R}^{2}$ & $\mathrm{~N}_{\mathrm{ICU}, \mathrm{e}}$ & $\mathrm{C}_{\mathrm{ICU}}$ & $\mathrm{k}_{\mathrm{ICU}}$ & $\mathrm{R}^{2}$ & $\mathrm{R}_{\mathrm{ICU}}$ & SD & $\mathrm{R}^{2}$ \\
\hline Austria & 111.9 & 3.6 & 0.067 & 0.977 & 14.6 & 5.2 & 0.041 & 0.967 & 0.168 & 0.005 & 0.912 \\
\hline Belgium & 226.9 & 3.2 & 0.084 & 0.993 & 66.1 & 0.3 & 0.090 & 0.996 & 0.161 & 0.002 & 0.986 \\
\hline $\begin{array}{l}\text { Czech } \\
\text { Republic }\end{array}$ & 0 & 26.9 & 0.063 & 0.995 & 0 & 9.8 & 0.052 & 0.995 & 0.149 & 0.002 & 0.976 \\
\hline France & 4806.7 & 11.1 & 0.082 & 0.996 & 230.5 & 76.1 & 0.041 & 0.992 & 0.178 & 0.006 & 0.819 \\
\hline Italy & 1174.6 & 21.3 & 0.075 & 0.993 & 78.5 & 2.1 & 0.074 & 0.993 & 0.095 & 0.001 & 0.993 \\
\hline Portugal & 320.5 & 10.7 & 0.056 & 0.993 & 32.6 & 2.9 & 0.049 & 0.990 & 0.153 & 0.003 & 0.964 \\
\hline Spain & N.R. & 9.0 & 0.115 & 0.956 & N.R & 7.0 & 0.086 & 0.962 & 0.145 & 0.003 & 0.907 \\
\hline $\begin{array}{l}\text { United } \\
\text { Kingdom }\end{array}$ & 560.8 & 64.2 & 0.058 & 0.989 & 0 & 37.2 & 0.039 & 0.989 & 0.109 & 0.003 & 0.944 \\
\hline
\end{tabular}

Legend: N.R = Not Reported for Spain because of the different time window selected $R^{2}=$ coefficient of determination

$\mathrm{SD}=$ standard deviation 